Cómo citar este artículo en MLA: Calabrese, C. "La metafísica platónica en los fundamentos del dualismo religioso. Una exégesis valentiniana del prólogo de San Juan”. Escritos 27. 58

(2019): 70-94. doi: http://dx.doi.org/10.18566/escr.v27n58.a04

Fecha de recepción: 13.02 .2019

Fecha de aceptación: 06.05.2019

\title{
La metafísica platónica \\ en los fundamentos del dualismo religioso. Una exégesis valentiniana del "prólogo" de San Juan
}

Platonic Metaphysics in the Foundations of Religious Dualism. A Valentinian Exegesis Of "The Prologue" Of Saint John

A metafísica platônica nos fundamentos do dualismo religioso. Uma exegese valentiniana no prólogo de São João

\section{Claudio César Calabrese ${ }^{1}$ [D}

1 Doctor en Letras por la Universidad del Salvador, Argentina y Doctor en Filosofía por la Universidad de Barcelona, España. Profesor del departamento de Humanidades de la Universidad Panamericana, Aguascalientes, México.

Correo electrónico: ccalabrese@up.edu.mx 


\section{RESUMEN}

La tesis del presente artículo sostiene que los fundamentos de una teología dualista de raigambre cristiana se encuentran en la interrelación entre metafísica platónica, mito gnóstico y exégesis; por tal motivo, hacemos especial énfasis en cómo la metafísica platónica se plasmó de un modo completamente diverso de lo que se conoce como "metafísica del Éxodo". Consideramos que el mito como vehículo expresivo de una experiencia religiosa constituyó, con su lógica polivalente, un elemento decisivo para la expresión de la tradición gnóstica. Nos detenemos en la comprensión del "Prólogo" de San Juan, que se centra en la función cristológica de Jesús, con las dificultades que implica la indiferencia con que dicha tradición consideró la Encarnación. Entendemos que las herramientas de esta exégesis provienen de la tradición helénica, en cuanto modo de precisar su intuición de las etapas de la propagación divina, tanto en la caída cósmica como antes de ella.

\section{Palabras clave:}

Gnosticismo valentiniano, Metafísica platónica, Mito, Exégesis, Dualismo.

\section{ABSTRACT}

The purpose of the article is to show that the foundations of a dualistic theology of Christian roots are found in the point of connection between platonic metaphysics, gnostic myths and exegesis. It highlights the way in which platonic metaphysics was developed in a completely different way than what is known as "Metaphysics of Exodus". It considers that myth - as an expressive vehicle of religious experience and having a polyvalent logic- was a decisive element for the transmission of gnostic tradition. Thus, the article concentrates on the gnostic understanding of "The Prologue of John", which focuses on the Christological function of Jesus, bearing in mind the difficulties involved in the indifference with which this tradition dealt with Incarnation. The tools for the exegesis are taken from Hellenic tradition as a form to clarify the gnostic intuition concerning the stages of the propagation of the divine, both before and after the Fall.

\section{Key Words:}

Valentinian Gnosticism, Platonic Metaphysics, Myth, Exegesis, Dualism.

\section{RESUMO}

A tese desse artigo afirma que os fundamentos de uma teología dualista de caráter cristã apontam à inter-relação entre metafisica platônica, mito gnóstico e exegese; salientamos, especificamente, como a metafisica platônica se formou de um modo diferente do que se conhece como "metafisica do Êxodo". Consideramos que o mito - como meio expressivo de uma experiência religiosa - constituiu, com sua lógica polivalente, um elemento decisivo para a expressão da tradição gnóstica. Estudamos sua compreensão do Prólogo de São João, que foca sua atenção na função cristológica de Jesus, com as dificuldades que ocasiona a indiferença dessa tradição ao considerar a Encarnação. A nosso ver, as ferramentas desta exegese 
provêm da tradição helênica, enquanto modo de precisar sua intuição das etapas da propagação divina, tanto na queda cósmica quanto antes dela.

Palavras chave:

gnosticismo valentiniano, metafisica platônica, mito, exegese, dualismo.

\section{Introducción}

El "Prólogo" de San Juan ha resultado, sin lugar a dudas, una fuente de reflexión no solo teológica sino también filosófica y, por esta razón, siempre será el Fausto de Goethe quien nos coloca dramáticamente ante sus dificultades al poner de manifiesto su dificultad al intentar traducir las primeras líneas del "Prólogo". Esto resulta ciertamente comprensible, pues en aquellas líneas se encuentra uno de los misterios más hondos de la doctrina cristiana: el Logos. Cómo traducir ese Logos es justamente el núcleo del problema de Fausto.

En este trabajo nos proponemos probar que, en la exégesis valentiniana del "Prólogo" del libro de San Juan, es decir, en la interrelación entre metafísica platónica, mito gnóstico y exégesis propiamente dicha, se encuentran los fundamentos de una teología dualista de raigambre cristiana, que entró tempranamente en polémica con la tradición protocatólica, como lo atestigua el texto de san Ireneo, que orientó esta misma doctrina platónica hacia lo que se denominó "metafísica del Éxodo". Consideramos la matriz metafísica platónica desde el Platón que nos presenta Aristóteles en el libro B de su Metafísica, según la relectura de Plotino, especialmente en los pasajes de la Ennéada V, que tendremos en cuenta especialmente. Hacemos, en efecto, literalmente propios los elementos que el Estagirita refiere de su maestro, es decir, no nos preguntarnos qué entendió de la filosofía platónica y no ingresamos en el tema concomitante de las enseñanzas no escritas de Platón.

De estos textos nos interesa particularmente la afirmación de que el Ser es una cierta ousía, es decir, que la esencia del Ser es el ser mismo. Este principio ha tenido muy amplias repercusiones en el desarrollo ulterior de la filosofía y de las teologías. Con el plural "teologías" nos referimos tanto a la identificación de Dios como el Ser (interpretación de Éxodo 3, 14), en el sentido que conlleva 
la expresión -antes mencionada- "metafísica del Éxodo" (Gilson 39-62), cuanto a su aplicación por parte del gnosticismo valentiniano, al menos en la interpretación del mencionado texto joánico.

Esta aplicación tiene un contexto inédito, propio de la Antigüedad Tardía: el recurso del mito para expresar una experiencia considerada inasible de lo sagrado, tal como se expresó en el cristianismo de cuño gnóstico. Por esta razón, juzgamos de importancia hacer una presentación de esta cuestión en lo que atañe a la comprensión de la experiencia del gnóstico y su presencia en el momento de la exégesis. La captación de lo Uno en su propia naturaleza, es decir, como único, encuentra su nota distintiva en la ausencia de partes, aunque esta no es la única, pues de ella fundamentalmente deriva la indiscriminación entitativa: lo Uno no es ser ni apariencia de ser. Cuando la indiscriminación entitativa, a la que hicimos referencia más arriba, se implica en la exégesis, encontramos lo que la tradición valentiniana (Haer. I, 11, 1) considera una diada innominable, que de manera complementaria se denomina Inefable y Silencio. ${ }^{2}$ Se trata, en definitiva, de seguir el proceso por el cual la metafísica platónica, en el modo específico de la exégesis gnóstica, deviene teología dualista, en disyunción con la anteriormente mencionada interpretación de Éxodo 3, 14.

En este sentido, la tensión entre el evangelio de Juan y la exégesis que más adelante consideramos se presenta muy especialmente en la situación de Jesús respecto del misterio de Dios. Su evangelio reitera esta vinculación entre sujeto particular y predicado universal, entre el hombre Jesús y el Hijo de Dios. "Podéis conocer el espíritu de Dios por esto: todo espíritu que confiese que Jesús ha venido en carne es de Dios, pero todo espíritu que no confiese a Jesús, ése no es de Dios, es el anticristo" (1 Jn 4,2). Sus textos representan una respuesta a la identidad de Jesús: es el Cristo, el Hijo de Dios hecho carne. Este Hijo es el salvador del mundo. No hay ya separación posible entre historia (Jesús), salvación del hombre (Mesías), proyecto de Dios (origen y envío de su Hijo). Debemos tener presente las dificultades del tema, pues la tradición gnóstica de raigambre cristiana consideró con indiferencia la Encarnación.

2 No es relevante para nuestro análisis que de esta díada surgiera una segunda, Padre y Verdad, de la que surgen a su vez dos Límites: Abismo o Padre no engendrado y los eones engendrados. 
En razón de lo anterior, nuestro trabajo consta de tres momentos: a) presentación de la metafísica platónica según la refiere Aristóteles en su Metafísica y su aplicación a la exégesis del Prólogo de Juan;’3b) aproximación al sentido del mito que se aplica a la comprensión de la revelación; c) la exégesis gnóstica del Prólogo de Juan (texto del s. $\mathrm{II}^{4}$ ), que contiene una interpretación de las relaciones Padre-Hijo; d) conclusiones.

\section{La metafísica platónica al servicio de la exégesis gnóstica}

La tradición griega define a la metafísica como "la ciencia del ser en cuanto ser" y la considera, por ello, como la más general, significando con ello que es la más elevada; Aristóteles (Metaph. III, 1, 1003 a 21-26) nos ofrece la definición canónica del estudio del ser en cuanto tal y de sus atributos esenciales. Todos los axiomas se reducen al principio de identidad, el que, para Aristóteles, es el principio supremo del conocimiento (III, 3, 1005 a 19-31), en cuanto ley fundamental de la ontología (condición de su ejercicio y de su aplicación), que afirma la relación del ser consigo mismo o la necesidad inmanente del ser en cuanto tal.

Aristóteles atribuye a Platón, como parte de la herencia pitagórica, la afirmación de que el ser no es otra cosa que ov̉oí $\tau \tilde{\omega} v o ̋ v \tau \omega v^{5}$. La relación entre cada cosa y la pregunta por su "qué es" presupone la dificultad central, de donde emerge la pregunta radical: ¿qué es lo que es? Con el término ousía, Aristóteles la precisa aún más: ¿cuál es el ser de lo que es? La respuesta que el Estagirita rescata

3 En esta perspectiva afrontamos, al mismo tiempo, la relectura plotiniana, no en un sentido histórico-causal, sino como la preparación de un instrumento exegético disponible para los maestros gnósticos del siglo III.

4 Se trata de una precisión metodológica, puesto que -como se sabe- el término "gnosticismo", debido a su inusitada riqueza doctrinaria e histórica, conlleva un uso que puede resultar ambiguo desde el punto de vista científico. Esto también lo afirmamos en relación con referentes bibliográficos presentes en este trabajo, como: Puech, En quête de la gnose; y H. Jonas, Gnosis und spätantiker Geist, I: Die mythologische Gnosis, que utilizan el término lato sensu.

5 Metaph. B 1, 996 a 5-7. "La entidad de las cosas que son". 
de su maestro se centra en que la ousía del ser es el ser mismo. La pregunta de Aristóteles, en el pasaje al que hacemos referencia, parece orientarse en la cuestión central, la que causa mayor perplejidad, es decir, si Uno y Ser no son otra cosa que la sustancia misma de cuanto existe.

Poco más adelante (B 4, 1001 a 5-12; 23-24) señala que si no se admite que el Uno y el Ser sean una cierta ousía no se podrían plantear el resto de los universales; en el mismo sentido, si el Uno no es una cierta ousía tampoco existiría el número como una naturaleza separada. Esto que Aristóteles considera desconcertante (1028b2-5) significa que se trata de una pregunta permanente, es decir, al estilo propiamente platónico, las respuestas no son definitivas; pero permiten dotar a la pregunta de una precisión creciente; en metafísica, por consiguiente, la ciencia del ser es algo que buscamos. A diferencia de cada una de las diversas ciencias particulares, una ciencia del ser no puede ser constituida y distinguida como tal, teniendo como referencia un solo género. Si lo entendemos incluso como lo más comprensivo, del cual cada cosa que existe "forma parte de", el ser tendría que tener un significado unívoco, pero de hecho, como Aristóteles reconoce repetidamente, "el ser se dice de muchas maneras".

Por ello, inmediatamente, toma distancia de la afirmación en estos términos:

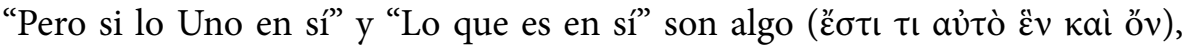
entonces necesariamente su entidad consistirá en ser-uno y en "ser lo que es"; en efecto, no se predica ningún otro universal de ellos que ellos mismos (Metaph. 1001 a 25). Propone, sin embargo, una fuente alternativa de unidad: la referencia conjunta de cada uno de los diversos significados de ser a uno primario (por ejemplo, Metaph. 1003a 33-bl9), y que, por ello, es ousía (Metaph. 1028 a 13-20, 1045 b 25-32).

Platón, en cuanto heredero de la intuición fundamental de Parménides, busca definir lo que denomina őv $\tau \omega \varsigma$ őv (vere ens, en terminología escolástica y con las dificultades que veremos más adelante); con este giro, Platón designa el conjunto de los objetos de conocimiento a los que les corresponde la afirmación de seres en cuanto de ellos puede afirmarse que son. La denominación de ser corresponde a ser uno mismo en cuanto que uno mismo; la identidad de la cosa consigo misma resulta la característica propia del ser, pues la relación entre identidad y realidad descansa en la igualdad (para una cosa, ser es ser lo 
que es). Para la doctrina platónica, entonces, la identidad de una cosa consigo misma es la condición de realidad, pues el ser es aquello único, idéntico y exento de cambio: las cosas son aspectos de esta identidad fundamental.

En Platón, ousía designa la permanencia de la cosa en identidad consigo misma y por ello la traducimos sea por "ser", sea por "esencia", no sin dificultades.

[...] examina entonces, Cebes, si de todo lo dicho no resulta esto: que el alma es lo más semejante a lo divino, inmortal, inteligible, único en su aspecto, indisoluble y que se comporta siempre del mismo modo e idénticamente a sí mismo ( no inteligible, de múltiples aspectos, disoluble, y que jamás se comporta idéntico a sí mismo (Phaed., 80 b).

Lo que, según este pasaje, podemos denominar "auto-ipseidad" se sostiene en la oposición entre lo mismo y lo otro, en cuyo seno se manifiesta la antítesis entre "lo que es siempre" y "lo que es nunca". Desde Platón, la metafísica tiene que ser ciencia productiva y solo puede tener las fuentes del entendimiento y de la experiencia como presupuestos en los que apoyarse para alcanzar lo que sobrepasa a ambos, es decir, lo suprasensible; en esta concepción metafísica no hay propiamente sistema que proceda a través de los objetos, sino que con cada ousía todo comienza nuevamente desde el principio (Cruz Cruz 216-217).

Como Platón explica en el Parménides (133 c-d), las ideas no explicitan nada de lo que para nosotros existe: "En consecuencia, aquellas realidades que son lo que son unos respectos de otros tienen su ser en relación consigo mismos y no en relación con los que están en nosotros -se los considere a estos como semejanzas o como fuere- de las cuales recibimos, en cada caso, sus nombres, en cuanto participamos de ellos".

De esta cita nos interesa poner énfasis, en conexión con nuestro tema, en que la única vía por la que es posible dar acceso al conocimiento resulta de su divinización, es decir, de transformar una esencia en un existente. ${ }^{6}$ Esta

6 De otro modo, como se insiste en el ambiente marcadamente escéptico de la Academia Nueva, no es posible adquirir ciencia de las ideas. 
dificultad de fundamentar el conocimiento de lo real movió a Platón a colocar la ousía en un "más allá" a partir del cual se torne inteligible; así en el Sofista, donde se replantea el problema del ámbito de las estructuras de las ideas y considera la consistencia de la noción de no-ser (237 b), la experiencia de la identidad lo lleva a identificar ser y uno (238d - 239a); en República (VI, 509 b) la identidad recae sobre el Bien, por lo que queda todo subordinado a este

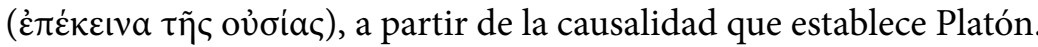

En continuidad (y en ruptura) con este pensamiento, Plotino establece un primer principio, que denomina "lo innombrable", á $\rho \rho \tau \tau o v ~(V, 3,13$ y IV, 9,5 ), aunque también dispone para él de dos nombres, Uno y Bien. Con "innombrable" parece significar lo que no es propiamente una cosa y que, como tal, se encuentran más allá del ser. "Porque lo no-uno es conservado por lo Uno, y gracias a él, es lo que es; y si una cosa hecha de múltiples partes no deviene una, todavía no se puede decir: ella es. Y si se puede decir de cada cosa lo que es, es eso gracias a la unidad y también a lo idéntico" $(\mathrm{V}, 3,15)$.

Queda claro que la identidad es algo distinto de la unidad participada, pues es unidad sin huella de multiplicidad; el Uno es la fuente de la unidad participada, por lo que resulta causa de identidad de todo lo que es (Enn. III 8, 10; V, 4). Plotino nos ubica aquí en el corazón de lo inefable, pues el Uno trasciende el ser, el que consecuentemente pasar a tener una consideración secundaria entre los principios. Escribe Plotino sobre la condición de inefable del Uno:

Y por eso es también verdaderamente inefable. Porque digas lo que dijeres, dirás algo. Pero la expresión «más allá de todas las cosas y más allá de la inteligencia más augusta» entre todas es solo verdadera no si es una denominación de aquél sino si aquel no es uno entre todos ni hay «nombre de él», porque nada se predica de él. Pero nosotros tratamos de designárnoslo a nosotros mismos como podemos (Enn. V, 3, 13.).

En cuanto el Uno no es el ser, puede causarlo. Esta afirmación, que Plotino reitera a lo largo de su obra resulta central en tanto que cada ser es una unidad particular, pero no el Uno:

El Uno es todas las cosas y ni una sola. Porque el principio de todas las cosas no es todas las cosas, pero es todas ellas en este sentido: por razón de que 
se introdujeron allá, por así decirlo. Mejor dicho, todavía no existen, pero existirán. - ¿Entonces, como pueden brotar de un Uno simple, si en lo idéntico no aparece variedad ninguna ni dualidad ninguna de cualquier cosa que sea? - Pues precisamente porque ninguna cosa había en él, por eso brotan todas de él, y precisamente para que el Ente exista, por eso él mismo no es Ente, sino Progenitor del Ente. Y ésta es la primera como procreación. Porque el Uno, siendo perfecto porque nada busca, nada posee, nada necesita, se desbordó, por así decido, y esta sobreabundancia suya ha dado origen a otra cosa y ésta, una vez originada, tornóse hacia aquél y se llenó y, al mirado se convirtió de hecho en esta Inteligencia. Su detenimiento frente a aquél dio origen al Ente; mas su mirada hacia aquél dio origen a la Inteligencia. Así pues, como se detuvo para mirado, conviértese a la vez en Inteligencia y en Ente (Enn. V, 1, 1).

Tan radical es la antinomia entre el Uno y el pensamiento que el Uno no puede pensarse a sí mismo, pues, para ello, debería desdoblarse en cognoscente y conocido. En la metafísica del Uno, Plotino establece que este es todas las cosas y ninguna (Enn. V, 2, 1); ello significa que lo que está en las cosas es el ser, una emanación del Uno, que no es lo Uno, pues este -como se señaló- no es ser. La consideración propiamente especulativa versa sobre un objeto que no puede ser hecho mediante el saber que sobre él se tiene: la razón posee la verdad especulativa cuando se regula por lo que es o realidad (Cruz Cruz 216-217).

En este punto resulta altamente clarificador volver sobre la etimología que Plotino propone para عĩval.

Decir que este Ser proviene del Uno, es atinar con la verdad. Lo muestra la denominación de 'Esencia'. En efecto, esto que llamamos 'Ente' es lo primero que provino del Uno: adelantándose, diríamos, un paso no más, no quiso seguir adelante, sino que, vuelto hacia adentro, se detuvo, y así, se convirtió en Esencia y Hogar de todas las cosas [...] (Enn. V, 5, 5.).

Para Plotino, el verbo ser no cumple con una función meramente copulativa. No dice lo que las cosas son, sino que "son," que "están siendo" ahora. Y este "siendo" tiene la característica de la unidad absoluta: lo que permanece indiferente ante los cambios de las cosas singulares o, en otras palabras, que las cosas sean algo ahora y luego algo diferente. En sede platónica, esto implica reconocer la existencia del no ser, pues "ser algo" conlleva al mismo tiempo "no ser otra cosa". 
En una doctrina, sin embargo, en la que ens deriva de esse, la emanación conduce, en un sentido absoluto, al panteísmo o al monismo. En efecto, esta semántica latina, la medieval más específicamente, resultó la doctrina común de los autores creacionistas, pues al pensar al ser como creado, implicó al mismo tiempo considerar al ente como una esencia posible que se vuelve realmente existente en el momento que su causa, el Ser, le otorga su existencia actual, en términos de accidente (Filippi 99-115).

Se observa, en este contexto, hasta qué punto esta postura metafísica ha alcanzado una transformación desde sus raíces. En la perspectiva que señala Plotino, es decir, considerada en su tradición semántica, por el contrario, el Uno es anterior a los seres y permanece en sí mismo: no se confunde con lo que engendra. El ser no es ya la materia de lo real, puesto que más allá del ser, y en su misma fuente, está el no-ser que es el Uno.

\section{Una aproximación al sentido del mito}

La concepción del tiempo como repetición indefinida de períodos propiamente únicos, en los que se suceden ciclos de orden y caos, se expresa en las cosmologías greco-latinas (Puech 1-23). ¿En qué nos desafía el mito? En principio, en traspasar los límites del entendimiento, comprendido como concatenación axiomática. Si lo expresamos dentro del dominio de la semántica griega, diremos que se trata de pensar el nous más allá de su función arquitectónica, pero "a partir" de ella.

Si esto es así, se comprende que se tata de incorporar el hacer y el entender del arte o poiesis en la médula de la teoría, en tanto propedéutica y culminación, al mismo tiempo. En la misma dirección, y como un segundo desafío del mito, este obrar del arte se coloca también en el corazón de la comprensión ética, reunificando intelecto, estética y ética.

Así considerado, la formalidad de la lógica no es el único modo de acceso a la comprensión de lo real, sino que el arte se transforma en una vía sorprendente para "acceder a" y para "culminar" la metafísica. Se trata de volver la comprensión a su raíz ontológica, es decir, aquello que se establece como ganancia en tanto se comprende en su sentido más genuino. 
Esta concepción convive, durante los primeros siglos de nuestra era, con una cierta tipología de creyente cristiano, que se reconocía como gnóstica, y cuya concepción resulta, en lo esencial, tanto una continuidad de aquella comprensión mítica cuanto un diálogo (y disyunción) con la concepción histórica que prevaleció en el cristianismo. Con aquella actitud se da la peculiar situación del mito ante la Revelación judeocristiana; el gnóstico es el que, transformado por la experiencia de la gnosis, remite a esta mediante un mito (relato verosímil e imaginario), que echa raíces, por lo común, en los primeros capítulos del Génesis. Apuntamos esta cuestión del mito porque implica lógicamente un modo de hermenéutica apta para comunicar una experiencia considerada inamisible.

Esta hermenéutica está determinada por los cuatro momentos narrativos del mito: a) el Dios desconocido y la manifestación de su plenitud, b) el desliz de Sabiduría, c) la presencia del Salvador y d) el retorno a la Plenitud. Se trata de instancias que sucesivamente se retrotraen a su raíz, o sea, que penden del contacto con la divinidad desconocida (García Bazán 21-24).

La gnosis se caracteriza por una tendencia a huir del mundo, a abandonar la realidad terrena, liberándose de los vínculos que ella impone; el gnóstico busca realizar su esencia, rehuyendo toda calificación mundana y objetiva. A esto llamamos espíritu "acósmico": la oposición radical, cosmológica y antropológica, entre hombre y mundo, entre el Dios trascendente y el cosmos y, en el interior del hombre, entre cuerpo y psique, determinaciones plenamente mundanas, y el pleroma, la chispa divina.

El carácter paradójico de la gnosis reside en el hecho de que la relación conflictiva con el cosmos se traduce, sin embargo, en una caída en el mundo, tal como se expresa en su narración mítica, que conduce a dinámicas psicológicas inmanentes: la meta de la liberación del mundo conduce a una recaída en él.

\section{La exégesis gnóstica del "Prólogo" del evangelio de San Juan}

La gnosis de cuño valentiniano expresa lo divino como un movimiento interno a Dios mismo: se trata de la interpretación teológica del mito gnóstico, 
pues no expresa un dualismo preexistente del que debe dar cuenta, sino que se comprende a partir del propio principio que saca a luz su exégesis (Bermejo Rubio 55-79). De ella, en efecto, emerge el núcleo cosmo-teándrico: el drama de la pérdida y de la recuperación del Logos (Alby 83). Debemos tener en cuenta que, cuando prestamos atención a una palabra del pasado, las incongruencias o vacíos que podamos hallar son un problema para nosotros, que buscamos una respuesta desde nuestro presente cultural; por el contrario, para aquellos que desplegaron una interpretación, en un contexto determinado, tal problema era inexistente. En el caso que nos ocupa, la gnosis de cuño valentiniano, hay un trasfondo mítico, cuyo sentido último, su propia coherencia interna, no se encuentra en tela de juicio (Romerales Espinosa 11-30).

El exégeta gnóstico rebusca en el texto joánico dónde y cómo emitió Dios a su Hijo, pues el Logos, en lo divino, y la materia, en lo cósmico, proceden de Dios por generación (lo divino) y por creación (la materia amorfa). Es evidente, en el texto, que esto resultaba racionalmente claro al gnóstico y que el misterio propiamente dicho empezaba con la cuestión del origen absoluto del Logos en Dios.

Aquí opera la transformación místico-filosófica que se orienta hacia un proyecto salvífico, que se encuentra en el interior del mito, pero que, en el destino del Cristo-Hombre, asume una realización práctica. Así como el mito en su relato crea las condiciones objetivas para la percepción de la gnosis, este debe ser interiorizado, en el sentido de reconducido hacia el sujeto, y desde allí recrear una metafísica y una mística. Entendemos que esta transformación permanece siempre vinculada al mito, pues el movimiento de autointerpretación del principio divino deviene éxtasis, pues culmina en una deificación del hombre, es decir, en una unión con Dios.

Como señalamos más arriba, hay dos temas de hondo significado que en la tradición valentiniana quedan plasmados a contraluz en la exégesis del "Prólogo" de San Juan: si no hay referencia mediata o inmediata de dónde engendró Dios al Logos y de dónde sacó la substantia materiae, podemos pensar que San Ireneo considerara la existencia de una masa previa que contuviera la sustancia racional e irracional sobre la que luego obraría el Logos (la materia supra lunar y la infra lunar o psique irracional). En este sentido, San Ireneo considera, al igual que Calcidio (In Timaeum c. 316), que los cuatro elementos no se explican por el obrar del Demiurgo o Logos, sin la existencia de una materia prima sobre la que sí obraría el Demiurgo. 
Si gnóstico es sencillamente quien posee la gnosis, ésta se caracteriza como un conocimiento salvífico, el cual -una vez obtenido- no puede perderse, es decir, que no deja de actuar en quien lo ha alcanzado (García Bazán 16-25). Nos interesa concentrar esta amplia perspectiva en un punto: el modo en que el gnóstico expresa esta verdad salvífica que considera poseer; en primer término confirma que no hay correlato entre lenguaje, aquel que media la comprensión del mundo, y la conmoción que ha producido en aquel creyente la verdad que lo distingue como espiritual o pneumático.

Esta imposibilidad de expresar lingüísticamente, es decir, en los términos de la lógica, pues estos se encuentran excedidos por la magnitud de la experiencia, lleva a un modo específico de relato -sucesión de imágenes apelativas-, que se conoce con la denominación "mito gnóstico".

Resulta conveniente vincular la actitud anticósmica del gnosticismo con su comprensión decisivamente fragmentaria del tiempo (tanto como las imágenes en que se expresa); por tal motivo, aunque la investigación permanezca en los límites de su propia estructura poiética-conceptual, los elementos que provienen de su entorno cultural -el mito- provocan una renovación de su lógica interna y lo configuran en su intimidad (Puech 268-271).

El antinaturalismo propio de la gnosis conlleva una actitud de rebeldía ante la naturaleza; nos acercamos así a la catadura psicológica del gnóstico (tal vez la dificultad más acuciante para la comprensión de nuestra temática). Debemos aclarar en este punto, y en virtud de lo expuesto hasta aquí, que la tradición gnóstica, más allá de los vastos alcances culturales de su doctrina, no asimiló enteramente ni las cuestiones doctrinarias del cristianismo ni las posiciones metafísicas del helenismo. Sí debemos considerar en este punto su independencia de criterio, es decir, la voluntad de hacer propio todo aquello que no contradecía su visión del mundo.

Es importante señalar en este punto, junto con A. Orbe, en su comentario a Haer. I, 2, 3, que el origen más remoto del surgimiento de la materia se encuentra en el pathos que del eón Sofía se propagó a los restantes (157). La materia es amorfa en cuanto proviene de la ignorancia, del tedio, del miedo y de la disminución o de la suspensión del juicio (stupor). Por ello, el pathos del eón Sofía se tradujo en enthymesis, puesto que, separada del Pleroma, entró en 
una agitación incontenible, por no haber entendido nada de lo que sucedía. ${ }^{7}$ Este es el sustrato de la creación, es decir, la materia informe que dará lugar a: 1) la sustancia racional (Demiurgo, arcontes o ángeles del demiurgo y los hombres psíquicos); 2) la sustancia húmeda; 3) la sustancia luciente y 4) los cuatro elementos.

En este contexto, el Pleroma hace divino al Hijo, del mismo modo que la Ignorancia, también aplicada al Pleroma, da origen a la materia informe. Si tenemos presente que, para la tradición valentiniana los eones componen la Persona del Unigénito, se explica míticamente en la distinción de las dos regiones contrastantes (Pleroma o lugar de luz y Kenoma o región de las sombras). Este drama afecta al Hijo, pues el Kenoma agrega al Pleroma la creación, de la cual tiene necesidad el Hijo, pues sin ella no hay ni creador ni salvador. Esta es la posición que corresponde a la trascendencia absoluta, donde los gnósticos establecen la capacidad de la divinidad para generar; por ello, en estas especulaciones sobre la trascendencia del Pleroma, subyace el misterio del nombre de Dios.

La caracterización intelectual y psicológica de la tradición valentiniana puede comenzar a definirse por el antagonismo con que concibe la relación entre Dios y la creación; en efecto, Dios no podría tener responsabilidad sobre la creación, que es propiamente el mal, por ser Él trascendente en un sentido absoluto, en tanto inalterablemente puro y perfecto. En sentido estricto, Dios no gobierna el orden que creó ni este sirve de puente para el conocimiento divino; Dios interviene en el mundo solo para procurar una vía de escape a las almas.

Para la filosofía clásica-helenística, el movimiento regular expresa la acción de la divinidad sobre el mundo de los astros, el cual se degrada en la medida en que desciende al mundo sublunar, pero sin dejar de regular el ritmo; en consecuencia, el cosmos, en cuanto inteligible, es divino él mismo. La tradición

7 Haers. I, 4, 1: Enthymesin illius superioris Sophiae [...] separatam a superiore Pleromate cum passione dicunt, in umbra et vacuitatis locis defervisse per necessitatem: extra enim lumen facta est et extra Pleroma, infomis et sine specie quasi abortum, ideo quod nihil apprehendit. 
gnóstica mantiene esta configuración externa del cosmos, pero revoluciona su significado profundo: aquel orden, aunque reconocido como tal, se vuelve abrumador; los astros rigen tiránicamente el mundo sublunar; he aquí la transformación sustancial (Jonas 146; Pétrement 75).

Antes de entrar propiamente en la exégesis del "Prólogo" de San Juan, nos ocupamos de en un texto atribuido a Ptolomeo, discípulo de Valentín, para en principio establecer el modo de nuestra comprensión y posteriormente dar el contexto de nuestro fragmento.

Hacemos propio el principio establecido por Platón en El Sofista (263 a), según el cual el discurso no es discurso acerca de algo, sino de algo como sujeto de algo. Todo discurso sería verdadero a condición que decir fuera algo (la cosa dicha); por el contrario, decir "algo de algo" introduce la dualidad ("lo que alguien dice de...”); el Logos manifiesta las cosas mediante su palabra, que es su modo de estar junto a las cosas. Una precomprensión de lo que sigue radica en reconocer un sentido diverso del ser, de aquel que está ordenado por las necesidades de la lógica. Como señala Aristóteles (Peri herm. 19 a 17; 19 b 3-4), esta expresa eventos futuros que pueden ser o no ser, pues no han alcanzado aún el sentido del ser en acto; al ser en potencia no lo alcanzan las leyes de la lógica bivalente, pues no son ni verdaderos ni falsos, al momento de ser considerados: su realidad -la que es en ese momento- es sencillamente la que se puede considerar verdadera con más probabilidad. La exégesis gnóstica no puede responder a la lógica bivalente, pues su discurso, que depende del mito, debe adecuarse a una lógica polivalente.

El texto de San Ireneo, Adversus Haereses, se divide en cinco libros. ${ }^{8}$ Nos detenemos en específico en el Libro I, porque nuestro texto se encuentra inserto en él y porque aquí también hallamos lo esencial del sistema valentiniano. Ya desde el "Prefacio", San Ireneo presenta la meta de su obra; en efecto, escribe:

8 Nos servimos casi completamente de la traducción latina ya utilizada c. 421 por San Agustín, por ejemplo, en c. Iul., I, 3, 5, según la edición de A. Orbe ya citada y del texto Los Gnósticos de Montserrat Torrens; de manera auxiliar recurrimos a los fragmentos supérstites del texto griego, según la edición de A. Rousseau y L. Doutreleau, S. Irénée de Lyon, Contre les hérésies, 1979. 
“[...] he leído los tratados de los autodenominados discípulos de Valentín y además he tenido encuentros con algunos de ellos en orden a entender sus doctrinas $[\ldots]$ Por todo eso consideré necesario, querido amigo, explicarte sus extraordinarios y profundos misterios [...]".

La expresión referida a los misterios tiene un evidente sentido irónico; sería injusto pedirle a San Ireneo el ánimo tranquilo y desapasionado que esperamos de un scholar, pues tiene una actitud evidentemente pastoral frente a la escuela valentiniana. Sin embargo es necesario aclarar que ha tenido siempre ecuanimidad respecto de las fuentes, sin forzarlas en ningún momento.

En la primera parte del Libro I, San Ireneo traza los lineamientos de las doctrinas gnósticas ("“...] doctrina, que los profetas no anunciaron, ni el Señor ensenó, ni los apóstoles han transmitido"). Nos ocupamos ahora de estudiar la exégesis gnóstica y las advertencias de San Ireneo: lo que uno y otro leyeron en las fuentes, según se estudian en el siglo II, con arreglo a tradiciones ya definidas. Su contexto, en efecto, es la interpretación bíblica, que en un perfil alegórico, se ocupa de ambos Testamentos con precisión y coherencia, tanto entre los eclesiásticos cuanto entre los gnósticos.

A partir de I, 8 se nos presentan algunos ejemplos de exégesis que practicaban los gnósticos. Esto resulta de capital importancia para San Ireneo, pues los gnósticos aducen textos extrabíblicos e intentan coordinarlos con las parábolas del Señor (dar ficción de autoridad a sus enseñanzas, según el propio Ireneo). El esfuerzo exegético gnóstico, como lo presenta nuestro heresiólogo, está en orden a explicar lo que ha quedado fuera del Pleroma: en los últimos tiempos, el Señor ha venido a padecer para poner de manifiesto la pasión que había sufrido el último de los Eones, cerrando con ello sus penalidades (I, 8, 2).

Así el caso de la niña de doce años, hija de un jefe judío (Mt. 9, 23-26), que Cristo resucita es figura de Achamot; luego se pasa revista a los pasajes donde Cristo explicó la existencia de hombres espirituales, psíquicos y carnales (los pasajes analizados más significativos son: Mt. 27, 46; 26, 38-39; Jn. 12, 27; Lc. 9,61 ss y 19,5). La mujer que barre la casa y encuentra el dracma (Lc. 15, 8ss) es imagen de la Sabiduría superior, que perdió su intención, pero, una vez que todo ha sido purificado por la venida de Cristo, la reencuentra.Luego sigue la exégesis al "Prólogo" de San Juan, sobre la que nos detenemos: 
Enseñan, además, que Juan, el discípulo del Señor, ha señalado la primera Ogdóada. Dicen así, literalmente: 'Juan, el discípulo del Señor, queriendo hablar de la generación de todos los eones tal como el Padre los emitió, establece como principio al primero nacido del Padre, llamado Hijo Unigénito y también Dios, en el cual el Padre emitió , a modo de simiente, a todos los eones'. Y continúan: 'El Logos, según Juan, fue emitido por este principio y, en el logos, la entera substancia de los eones, a los que él mismo dio después forma'. Ya que Juan está hablando de la primera generación, hace derivar convenientemente su enseñanza del principio, esto es, del Hijo y del Logos, cuando escribe: 'En el principio existía el Logos, y el Logos estaba cabe Dios, y el Logos era Dios; este Logos estaba en el principio junto a Dios. En primer lugar distingue a los tres: Dios, Principio, Logos; luego los reúne de nuevo, para mostrar la emisión de cada uno de ellos - del Hijo y del Logos- y la unión que existe entre ellos y con el Padre. En el Padre está el Principio, y del Padre procede (Ireneo de Lyon, “Contra las herejías” 142).

Esta exégesis se encuentra en estrecha relación con la interpretación judeocristiana del Génesis, pues esta ya había vinculado aquel principio con Sabiduría; en el mismo sentido, San Pablo denomina a Cristo como Arkhé / Principium, Esta transposición entre Principio y Logos es propiamente gnóstica, pues ella resulta superflua para la interpretación eclesiástica. En esta correlación entre Principio y Logos, los términos hacen referencia a una realidad anterior a todo tiempo, aunque al inicio de una sucesión. ¿Qué rumbo entonces toma aquí la Cristología?

En principio, la cuestión central del misterio queda en pie; en efecto, si el entendimiento es el principio a partir del cual se plantea la posibilidad del conocimiento, entonces, ¿qué queda del misterio de ser al mismo tiempo hombre y Dios? Una respuesta posible resulta de la identificación, en su sentido más estricto: se cumple la generación del Unigénito allí donde tiene lugar la identificación entre unidad y dualidad. Antes de debatir los argumentos que aporta la exégesis valentiniana, debemos prestar atención a la estructura formal de su pensamiento: lo que aquí se entiende como emisión es estructuralmente una analogía con el concepto de Dios. Frente a la inefable simplicidad del Padre, la composición del Unigénito reclama nuestra atención, pues sintetiza un sinnúmero de perfecciones orientadas fuera de Dios (Verdad y Sabiduría, 
por ejemplo), es decir que la exégesis gnóstica tiene por objeto aquello que no es Dios (Fredouille86-89).

La lógica de la exégesis considera que, si "en el principio existía el logos" (estaba en el Hijo), la conjunción entre Principio y Logos solo puede significar que "Dios es Dios"; así expresado no conlleva una tautología para los gnósticos, pues pone de manifiesto "el orden de la emisión" (emissionis ordinem, I, VIII, 5); así interpretaban el texto evangélico "todas las cosas fueron hechas por Él”: tenía la significación de que el Logos fue la causa de la generación y formación de los eones posteriores a él. Resulta, por ello, el sentido que está detrás y por encima del sentido de las cosas que, al hacerse corporal, expresa el padecimiento de la materia.

En efecto, si leemos el texto citado en correlación con I, 2, 5-6 ([...] el Unigénito emitió todavía otro conyugio, según la providencia del Padre, Cristo y el Espíritu Santo [...] para fijación y consolidación del Pleroma"). El Unigénito es la síntesis de todos los eones del Pleroma, que se presentan como formas ejemplares, en las que se acentúa el dinamismo del universo todavía informe. En la teología valentiniana se considera entonces que se representa como persona, en cuanto referencia fundamental de la futura creación; por ello, el matrimonio Cristo-Espíritu Santo puede interpretarse como la profusión de lo divino sobre el Pleroma, llegando el Espíritu a cada uno de los eones (García Bazán 123-195).

En esta exégesis, el Unigénito no mira al Padre, sino "hacia afuera", es decir, hacia la creación que adviene (Troiano 623). Se entiende así que, en las doctrinas gnósticas, el Espíritu Santo no es estrictamente una persona de la Trinidad, sino que opera como una figura divina que no se distingue del Padre y del Hijo; es el modo en que la creación divina se manifiesta hacia el exterior, aunque -insistimos- sin distinguirse de Él.

9 [...] Monogenem iterum alteram emisisse coniugationem, secundum providentiam Patris, Christum et Spiritum sanctum a quibus consummatos ese dicunt Aeonas. El texto griego, a diferencia del latino, dice con énfasis que Cristo y el Espíritu Santo fueron emitidos "para fijación y consolidación del Pleroma", que colocamos en la traducción. Gómez de Liano, El círculo de la Sabiduría. Diagramas del conocimiento en el mitraísmo, el gnosticismo, el cristianismo y el maniqueísmo (Madrid 1998). 
Así como en la teología protocatólica, la posibilidad de la salvación está profundamente unida a la posibilidad del hombre de identificarse con Dios, el valentinismo parece, a cada momento, responder a una pregunta que podemos formular en estos términos: ¿puede Dios identificarse con el hombre? Y las distintas respuestas podemos ordenarlas a partir de la siguiente matriz: si el pecado, en la tradición judeocristiana, es una de las características centrales del hombre, los valentinianos, insertos en esta misma tradición, la aplicaron a la comprensión divina, en los términos siguientes: Dios se presenta como relación de personas (el sentido mismo de la Trinidad), en la que el Padre ama al Hijo, que es divino-humano; por esta razón no lo entendieron como propiamente único, sino que dieron un paso más: todo lo que está en el hombre está en Dios (pecado o mal incluido).

Esta respuesta afirmativa de la tradición valentiniana (Dios se ha identificado en todo, incluido en el mal) fundamenta las tensiones de su cristología; los procesos de esta identificación ponen de manifiesto la relevancia histórica y antropológica de nuestro estudio, a partir de la peculiaridad especulativa del mito. La cristología protocatólica, tal como lo advertimos en el propio San Ireneo, comienza, por el contrario, a definir que, con su muerte, Cristo asume la limitación humana. La condición de posibilidad de esta definición se encuentra precisamente en las raíces de la polémica anti-gnóstica.

Las imágenes que constituyen la exégesis, sin embargo, nos colocan en una unidad anterior a toda multiplicidad $y$, de aquí, el contenido ambiguo del principio: si el Logos es la unidad en Cristo, el infinito no admite entrecruzamiento alguno con lo finito; la unidad absoluta queda contenida en la absoluta autocomprensión de Cristo, principio pero no consumación de ese mismo principio. Cristo, en definitiva, deja de ser hombre, en tanto esta gnosis no se presenta con pretensiones salvíficas. Si bien la semántica de principim sigue en correlación con sentido de arkhé en el griego clásico y posclásico, aquí deviene fundamentalmente "principio ontológico".

Esto implica introducir una paradoja en la afirmación de San Juan, pues lo divino se entiende en cuanto articulación entre Padre, Hijo y el Amor que se tienen. Aquí se implica una novedad radical de orden teológico, pues se piensa a Dios como un eterno devenir en sí mismo. Sobre el trasfondo de la tradición cristina (Dios como misterio de amor entre las personas divinas), el 
valentinismo despliega su poderosa intuición: todas las características de lo humano son asumidas, como tales, por el principio divino.

La naturaleza incondicionada en que "el Padre emitió, a modo de simiente, todos los eones" configura la lógica de las imágenes y no a la realidad que busca estrechar. Esta estructura conceptual mítica, en la que se superponen niveles narrativos, se articula en la figura de Jesús como Logos preexistente, el Unigénito. Tal vez la insistencia, más marcada en San Juan que en los Sinópticos, de referir a Cristo como Unigénito, el Logos junto a Dios facilitó que los primeros comentarios al Evangelio de San Juan provinieran de maestros gnósticos; los asistía una cuestión en absoluto menor: la manifestación de Dios en forma humana es un acontecimiento reciente, pero es el primogénito de la creación, que de manera permanente tiende hacia ella. Se consuma así la separación típica del talante gnóstico: el Dios creador (Yaweh) del Dios Salvador o desconocido. En este contexto no resultaba posible una fe salvífica, sino un movimiento existencial de desvelamiento del verdadero significado del mundo.

Dios es substancialmente Dios, y el resto son atributos; para la exégesis precedente, Dios debe ser "Theós" para ser Padre; ya Tertuliano (Adv. Prax. 7, 1) había enseñado que ab aeterno Dios únicamente es Dios; luego, a manera de Verbo inmanente, concibe la Sabiduría y solo entonces pasa a ser libremente Padre. Para la interpretación gnóstica, Dios es Padre antes de la creación, cuando engendró al demiurgo del universo. La paternidad es ab aeterno, a partir de la proyección del Universo en el Unigénito.

Esto se observa cuando san Ireneo considera el tema fuera del marco exegético: el Hijo estaba siempre con el Padre y el Espíritu Santo lo asistía antes de la creación: "Tú, hombre, no eres increado, ni siempre coexistirás con Dios, como su propio Verbo; sino que, por su eminente bondad, después de haber ahora empezado a existir, aprendes poco a poco del Verbo las economías del Dios que te creó" (Haer. II, 25).

El Hijo nació hombre en el tiempo, pero estaba desde siempre junto al Padre. La exégesis valentiniana es contraria a esta posición, es decir, al Hijo eterno, en el sentido concreto de "eterno en futuro" (ab aeterno implica, por el contrario, "eterno sin limitación"); en el mismo sentido, Dios parecer tener indigencia respecto de Verbo, pues en Él coloca la clarificación absoluta de Dios. Esta 
parece la consecuencia directa de la postura de que el Hijo fue creado "en el principio", previo a la creación (Dios se vale del Hijo como Demiurgo).

Esto supone que el proceso supositivo del Hijo Unigénito pueda presentarse en tres momentos: a) la generación de todos los eones, que en cuanto tales son presencia pura que aspiran al Padre; b) el mutuo sustento de Dios, Principio y Logos; y c) el regreso al principio incondicionado en términos conclusivos, como principio carente de otro significado que las imágenes que lo muestran $y$, entonces, lo ocultan.

El ser de Cristo y "el modo de ser palabra de Cristo" introduce una dinámica completamente nueva en la humanidad, y la exégesis valentiniana intenta dar cuenta de ello: el pasaje de los seres individualmente agregados a la unidad de Dios; así el Logos es la unidad a la que regresa el gnóstico. Por ello es necesaria una especulación que se coloque por encima del culto: la comunicación directa con Dios es el único camino que el gnostikós considera viable para sí. Estas afirmaciones deben considerarse para su cabal comprensión, en clave metafísica antes que salvífica.

Si "gnosis" significa propiamente "conocimiento sobre Dios" y si Dios está caracterizado por la trascendencia absoluta, esto entraña que aquel conocimiento de Dios es el conocimiento de Alguien desconocido y no corolario de un proceso natural que pueda decir algo del "qué" de Dios.

Hemos seguido un movimiento circular en el que están implicados dos momentos fundamentales, salida y regreso de/a Dios; este modelo encontró diversos caminos de expresión; en general se concibió como un gran movimiento cósmico (cristianismo) o como iteración continua del tiempo (filosofía clásica y religiones naturales). La oposición no es, sin embargo, excluyente: para la visión cristiana del mundo, en el ciclo histórico que va de la salida al regreso, se encuentran los ciclos individuales de la vida, que se realizan, de modo nuevo cada vez, el gran movimiento del todo. En este movimiento no exento de dramatismo resuena la concepción explicitada por Plotino y que es determinante, aunque de manera diferente, en las diversas teologías cristianas y en cultos no cristianos. En efecto, en el inicio o surgimiento en el que aparece el ser no divino se expresa el descenso o caída de lo divino, hacia profundidades cada vez más ausentes de lo divino. 
Tal degradación en la caída implica una finitud raigal que debe ser salvada con el recurso del retorno a lo infinito. La metáfora plotiniana del regreso a casa (Enn. VI, 7, 35) expresa que la caída se ha detenido en un cierto estadio de profundidad, cuyo "no ser en Dios" regresa a "Dios llega a ser todo en todos". En este contexto, salvación significa liberación de la finitud, que es la verdadera marca de la existencia; por ello, "regreso" entraña un movimiento de interiorización de la caída y el regreso ascensional que ello implica.

En cuanto contemplación de este proceso, que se encuentra antes y por encima de toda existencia, la exégesis valentiniana concluye en que tal proceso consiste esencialmente en conocimiento (la esencia misma del regreso). Este es el punto por el cual la recepción de la verdad (sea a través de una tradición sagrada y secreta sea a través de la iluminación que se traduce en exégesis) sustituye la teoría propiamente dicha, aunque la experiencia intraducible del gnóstico o aquella exégesis como camino de iluminación puedan significar el inicio de una especulación paralela a la argumentación racional.

Como se observa en el propio San Ireneo de Lyon (II, 6), el cristianismo eclesiástico asume este mismo esquema, aunque con dos diferencias ciertamente decisivas: por un lado, el surgimiento o salida no es caída o ser que emerge como manifestación maligna, sino el acto creador de Dios, que dispone cosas intrínsecamente buenas, en tanto acto libérrimo; por otro lado, el regreso afecta a la criatura y es un llamado de Dios para que vuelva a sí misma, en uso de su libertad. La doctrina de Jesús no proviene, en definitiva, de ningún aprendizaje humano, sino del diálogo con el Padre; la existencia filial de Jesús es el origen íntimo de su ser-Palabra.

\section{Conclusión}

En la lectura creacionista se hace evidente la prioridad del bien a partir de la causalidad: el bien tiene carácter de fin, "la causa de las causas"; en efecto, la precedencia del bien en tal orden queda establecido por el punto de vista causal. Tal vez la discusión de Ireneo con los representantes valentinianos no sea ajena al establecimiento de la precedencia absoluta del Bien. En el modelo de exégesis que presentamos, la intelección se encuentra asociada a una recepción y a una 
interpretación inmanente de los datos. Tal interpretación, en tanto que acción del verbo humano en dirección al Logos, está direccionada por disposiciones que ponen de manifiesto el evento divino; el término inmanente de una acción es necesariamente de conformidad causal.

El Logos, considerado de manera inmanente, refleja las condiciones previas que expresan la naturaleza del Padre; por ello, la significación lógica del relato se expresa en correlación con la naturaleza inteligible -en un sentido absoluto--de Dios. En el prólogo joánico se produce una conexión manifiesta entre creación, revelación y redención: el Logos, en tanto partícipe de la acción creadora, revela y redime.

Entendemos que resulta de interés haber puesto de relieve que la exégesis gnóstica distingue la creación, que aquí significa "condenación" o, más propiamente, definibilidad del hombre frente a Dios, de la salvación que se comprende como "liberación" hacia la vida verdadera, aquella que es "luz de los hombres".

Como el gnosticismo de raigambre cristiana no se presenta como una religión histórico-salvífica, cósmica en tanto que escatológica, sino que descansa sobre fundamentos teosóficos, rescata el relato mítico como vehículo de la expresión de lo sagrado, con una mirada especial sobre la eternidad como no-generación. Por ello, para que el dispositivo platónico fuera aplicable a la experiencia religiosa gnóstica, aquel fue asimilado de una manera inusitada; en efecto, para expresar con precisión las etapas de la propagación divina y su relación con la caída cósmica, fue necesario que la exégesis desvirtuara el instrumento filosófico platónico: la explicación que Plotino ofrece sobre el Uno y su aislamiento refluyen en las intuiciones gnósticas que buscan explicar su peculiar expresión de lo divino. Así, para que el método exegético mantenga coherencia y la expresión intelectual ponga en evidencia aquella captación, su capacidad interpretativa debe entenderse como una ontogonía, que puede ser expuesta con el recurso del mito para justificar su visión de lo divino.

La presentación del Padre Inefable y del Unigénito conlleva una doble perspectiva: por un lado, en potencia, como simiente en la apercepción del Padre, desde el momento que en Silencio se llevan a cabo las representaciones del Pensamiento y de la Voluntad del Padre, a fin de concebir el embrión del 
Hijo. Por otro, la actividad de pensarse eternamente del Padre Incognoscible hace surgir propiamente la emanación. Estas actividades de emanación ponen de manifiesto que el Padre desconocido se dio a conocer a los eones y, a través del Pensamiento de sí mismo, como conocimiento que está en proceso de conocerse, emite al Unigénito. Por ello, el Hijo es conocimiento.

Esta dualidad en la unidad se presenta como equivalente a la relación uno-todo: posesión simultánea pero no separada de las partes; este modo de comprender la mónada conlleva estructuras de pensamiento platónicas que se manifiestan en términos de emisión.

Se expresa, de esta manera, un escalón de descenso respecto al sentido divino del mundo; no se da propiamente, en el gnosticismo, una teología sino una metafísica teológica, desde la que se hace posible concebir una liberación que reintegra al principio divino que permanece como desconocido.

Entendemos que las herramientas de la exégesis gnóstica, con todas sus peculiaridades, provienen de la tradición filosófica helénica, como posibilidad de precisar su intuición de las etapas de la propagación divina, tanto en la caída cósmica como antes de ella.

Consideramos que esta es la diferencia más profunda con la comprensión protocatólica, que comenzaba a forjarse en esta polémica y que se expresa en estos términos: quien ve a Jesús ve al Padre (Jn. 14, 9), por ello quien sigue al Hijo se incorpora en Él a la comunión Trinitaria; aquí parece radicar la superación de todos los límites humanos, en la realización de la imagen de Dios en sí.

\section{Referencias}

Alby, J.C. “El silencio del verbo según san Ireneo”. Teología y Vida, LIV/ 1 (2013): 79 91.

Aristóteles. Metaphysics. Cambridge, 1933.

Bermejo Rubio, F. "Lógica dualista, piedad monoteísta: la fisonomía del dualismo maniqueo". Ilu, Revista de Ciencias de las Religiones 12 (2007): 55-79.

Cruz Cruz, J. Intelecto y razón. Las coordenadas del pensamiento según Santo Tomás, Pamplona: EUNSA, 2009. 
Filippi, Silvana. "En torno a 'la metafísica del Éxodo"'. Studia Gilsoniana, 4.2 (2015): 99-115.

Fredouille, J-L. Tertullien Contre les Valentiniens. Paris : Éditions du Cerf, 1980-1981. («Sources chrétiennes») N 280-281.

Bazán, Francisco García. El gnosticismo: esencia, origen y trayectoria. Buenos Aires: Guadalquivir, 2009.

Gilson, E. Lesprit de la philosophie médiévale. Paris: Vrin, 1948.

Gómez de Liano, I. El círculo de la Sabiduría. Diagramas del conocimiento en el mitraísmo, el gnosticismo, el cristianismo y el maniqueísmo, Madrid: Siruela, 1998.

Ireneo de Lyon. "Contra las herejías”. En Los Gnósticos. Madrid: Gredos, 1990.

Jonas, H. Gnosis und spätantiker Geist, I: Die mythologische Gnosis. Göttingen: Verlag Vandenhoeck \& Ruprecht, 1934

Montserrat Torrens, J. Los Gnósticos, Madrid: Gredos, 1990.

Orbe, A. Teología de san Ireneo. Comentario al Libro V del "Adversus haereses". Madrid: BAC-Minor, 1985.

Orbe, A. Estudios sobre la teología cristiana primitiva. Madrid/Roma: Ciudad Nueva, 1994.

Pétrement, S. Le Dualisme chez Platon, les Gnostiques et les Manichéens. Paris: Presses Universitaires de France, 1947.

Puech, H-CH. En quête de la gnose.I. La Gnose et le temps et autres essais, Paris: Gallimard, 1978.

Plato. Phaedo, Oxford: Oxford University Press, 1975.

Plotin. Ennéades, Paris: Les Belles Lettres, 1976.

Romerales Espinosa, E. "El legado metafísico de las cosmogonías. Una tensión recurrente entre las concepciones monistas y las pluralistas". Éndoxa, 36 (2015): 11-29.

Rousseau A. - Doutreleau, L. S. Irénée de Lyon, Contre les hérésies. Paris: Ed. du Cerf, 1979.

Sanhueza, Kreti. Jesucristo, prototipo de justicia y martirio, a favor de los pobres y marginados. Cuestiones Teológicas, 43.99 (2016): 175-197.

Troiano, M. "De la substancia del diablo. Orígenes y la dinámica del sistema valentiniano de las tres naturalezas". Teología y Vida, 55.4 (2014): 607-629. 